\title{
Recovery of Platinum from Concentrated \\ Sodium Chloride Brine by \\ Electrodeposition on Vitreous Carbon
}

\author{
J. E. Harrar and F. B. Stephens
}

January, 1984

\section{DISCLAIMER}

This report was prepared as an account of work sponsored by an agency of the United States Government. Neither the United States Government nor any agency thereof, nor any of their employees, makes any warranty, express or implied, or assumes any legal liability or responsibility for the accuracy, completeness, or usefulness of any information, apparatus, product, or process disclosed, or represents that its use would not infringe privately owned rights. Reference herein to any specific commercial product, process, or service by trade name, trademark, manufacturer, or otherwise does not necessarily constitute or imply its endorsement, recommendation, or favoring by the United States Government or any agency thereof. The views and opinions of authors expressed herein do not necessarily state or reflect those of the United States Government or any agency thereof. 


\section{DISCLAIMER}

This report was prepared as an account of work sponsored by an agency of the United States Government. Neither the United States Government nor any agency Thereof, nor any of their employees, makes any warranty, express or implied, or assumes any legal liability or responsibility for the accuracy, completeness, or usefulness of any information, apparatus, product, or process disclosed, or represents that its use would not infringe privately owned rights. Reference herein to any specific commercial product, process, or service by trade name, trademark, manufacturer, or otherwise does not necessarily constitute or imply its endorsement, recommendation, or favoring by the United States Government or any agency thereof. The views and opinions of authors expressed herein do not necessarily state or reflect those of the United States Government or any agency thereof. 


\section{DISCLAIMER}

Portions of this document may be illegible in electronic image products. Images are produced from the best available original document. 
Contents

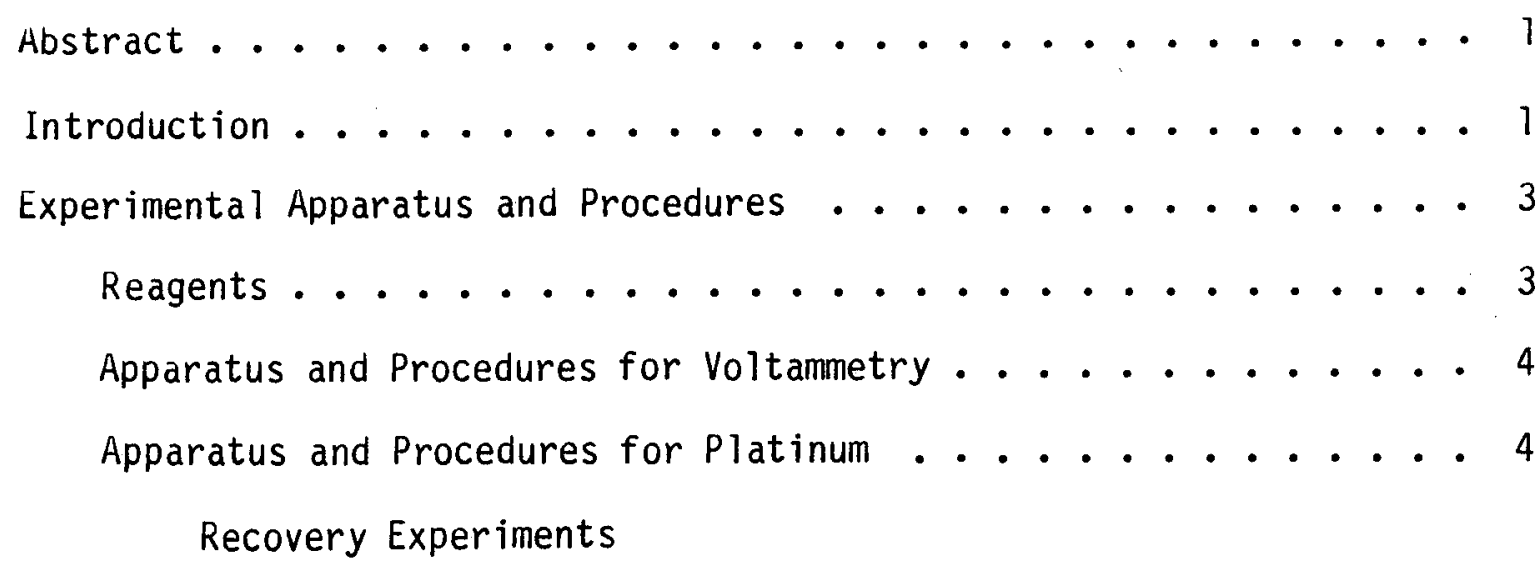

Results and Discussion of Voltammetric Measurements . . . . . . 8

Results and Discussion of Platinum . . . . . . . . . . 15 Recovery Experiments

Conclusions . . . . . . . . . . . . . . . . . . 18

Acknowledgments . . . . . . . . . . . . . . . . 19

References . . . . . . . . . . . . . . . . 20 
Recovery of Platinum from Concentrated Sodium Chloride Brine by Electrodeposition on Vitreous Carbon

\author{
J. E. Harrar and F. B. Stephens
}

\begin{abstract}
The voltammetric characteristics of $\mathrm{Pt}$ (II) and $\mathrm{Pt}$ (IV) have been examined at a vitreous carbon electrode in slightly acidic $3 \underline{M}(2) 5$ wt.\%) $\mathrm{NaCl}$ solutions. $\mathrm{Pt}(\mathrm{IV})$ is reduced to $\mathrm{Pt}(\mathrm{II})$ at $\sim_{0} \mathrm{~V}$ and $\mathrm{Pt}$ (II) is reduced to $\mathrm{Pt}(0)$ at $\sim-0.5 \mathrm{~V}$ vs. $\mathrm{Ag}-\mathrm{AgCl}$. The rate of deposition of platinum metal at $-0.5 \mathrm{~V}$ is very low on bare carbon, but increases as the coverage of platinum increases. The potential at which hydrogen is evolved in this medium is $\sim-0.85 \mathrm{~V}$. A technique has been tested for the removal of sub-part-per-million levels of platinum from the high-salinity brine by controlled-potential electrolysis using a reticulated, vitreous-carbon, flow-through electrode. However, at control potentials negative enough to begin to electrodeposit the platinum at a significant rate, simultaneous reduction of hydrogen ion reduces the current and energy efficiency to an unacceptable level.
\end{abstract}

\title{
Introduction
}

In a previous study (Harrar and Raber, 1983), in which a number of natural brines were analyzed for precious and strategically-valuable metals, it was found that one of the brines from the Salton Sea geothermal field contained approximately $50 \mu \mathrm{g} / \mathrm{kg}$ of platinum. Although this concentration is very low, the large volumes of fluid that are currently processed for energy extraction makes such a resource 
attractive if the precious metal could be economically extracted. The brines of the Salton Sea geothermal field (or KGKA = Known Geothermal Resource Area) are of extremely high salinity (15-20 wt \% salts), and are composed principally of sodium, potassium, and calcium chlorides.

The fluid that would most likely be processed for metals recovery would be the relatively low temperature $\left(<90^{\circ} \mathrm{C}\right)$ effluent brine from the power plant facility, after the principal flash stages for energy extraction. However, different geothermal plant designs involving high-temperature crystallizers for solids removal are currently being tested, and valuable metals recovery is certainly possible at the higher temperatures $\left(>200^{\circ} \mathrm{C}\right)$ of the wellhead brine. A literature survey of previous studies in geothermal mineral recovery can be found in our previous report (Harrar and Raber, 1983) and a paper by Maimoni (1983).

To continue our investigations, two approaches have been examined for removal of platinum from high-salinity geothermal brines. One involved the use of various solid chemical media that were known from previous studies in dilute waters to be effective in precious metal removal. Most of these media had been tested previously only for non-precious-metal or gold and silver removal (Acton, 1982) and in low-ionic-strength, low temperature solutions. The results of this study are being reported elsewhere (Raber, Thompson, and Gregg 1984).

The second technique examined for platinum recovery was electrolytic deposition on a substrate of vitreous carbon. For some of the elements, electrodeposition of the metals on inert electrode materials is performed for both metals recovery (Habashi, 1982; Ettel and Tilak, 1981; Coeuret, 1980), pollution control (Bennion and Newman, 1972; Kuhn, 1972) and for trace metals analysis (Murthy, Holzbecher, and Ryan, 1982). However, not only is there no knowledge of the conditions necessary for quantitative 
electrodeposition of trace amounts of platinum from aqueous solutions in general, but there is also no information on the electrochemistry of platinum in high-chloride media.

Accordingly, our first objective was to measure the current/electrodepotential characteristics of platinum in solutions of $\mathrm{NaCl}$ at concentrations simulating those of the high-salinity geothermal brines. Then, using these data, a series of experiments were carried out to attempt to quantitatively electrodeposit platinum from a flowing stream of brine. The electrode material selected was vitreous or "glassy" carbon. This material was selected because of its relative inertness, and because, for the flowing-stream experiments, it could also be obtained in the form of reticulated-vitreous carbon (RVC). This material (see Wang, 1981) is commercially available and is configured as a rigid, porous matrix that can be used advantageously in processes requiring large electrode surface area. Both the current-potential (voltammetric) and the flow-recovery measurements were performed using 3-electrode controlled-potential techniques so that the applied cathode potentials would be precisely known.

\section{Experimental Apparatus and Procedures}

Reagents. For the voltammetric measurements, the brine solutions were prepared from J. T. Baker Ultrex-grade $\mathrm{NaCl}$ salt. It was found that Mallinkrodt ACS reagent-grade $\mathrm{NaCl}$ contained sufficient heavy-metal impurities to raise the background current to an undesirably high level in these concentrated solutions. For the recovery experiments, however, the larger volumes of solution precluded use of the UItrex-grade salt, so the reagent-grade salt was used. 
Platinum(II) and platinum(IV) solutions were prepared by dissolving, respectively, $\left(\mathrm{NH}_{4}\right)_{2} \mathrm{PtCl}_{4}$ and $\left(\mathrm{NH}_{4}\right)_{2} \mathrm{PtCl}_{6}$ salts in water. These salts were obtained from Engelhard Industries as nominally high-purity compounds. The concentrations of platinum were calculated from the assays of the compounds as reported by the manufacturer. For the platinum recovery experiments, a solution containing $0.168 \mathrm{mg} \mathrm{Pt} / \mathrm{ml}$ and $0.002 \mathrm{M} \mathrm{HCl}$ was used.

Apparatus and Procedures for Voltammetry. To investigate the voltammetry of platinum, equipment consisted of an EG\&G Princeton Applied Research Model 174A Polarographic Analyzer, Model 303 Static Mercury Drop Electrode Assembly, and a Houston $X-Y$ recorder. A model G0173 glassy carbon electrode was substituded for the mercury capillary in the cell assembly. To prepare a solution for voltammetry, $5 \mathrm{ml}$ of brine was placed in the cell, and $1 \mathrm{ml}$ of a stock solution of either $\mathrm{Pt}$ (II) or Pt(IV) was pipetted into the cell to give a platinum concentration of $2 x$ $10^{-3} \mathrm{M}$. The $\mathrm{pH}$ of the cell solutions was in the range of 4 to 6 . Solutions were deoxygenated by bubbling high-purity nitrogen through them for at least 4 min. prior to the voltammetric scans. Nitrogen was flowed over the top of the solutions during the scans. All measurements were made at an ambient temperature of $22-25^{\circ} \mathrm{C}$.

Apparatus and Procedures for Platinum Recovery Experiments. The flow electrolysis cell shown in Figure 1 was used for the recovery experiments. Features of this flow-through RVC cell that differ from previous designs (Strohl and Curran, 1979; Wang and Dewald, 1983) are the dual counter- and reference electrodes and the use of low-temperature $\left(140^{\circ} \mathrm{C}\right)$ heat-shrinkable Tefzel to encase the RVC. The lower temperature 


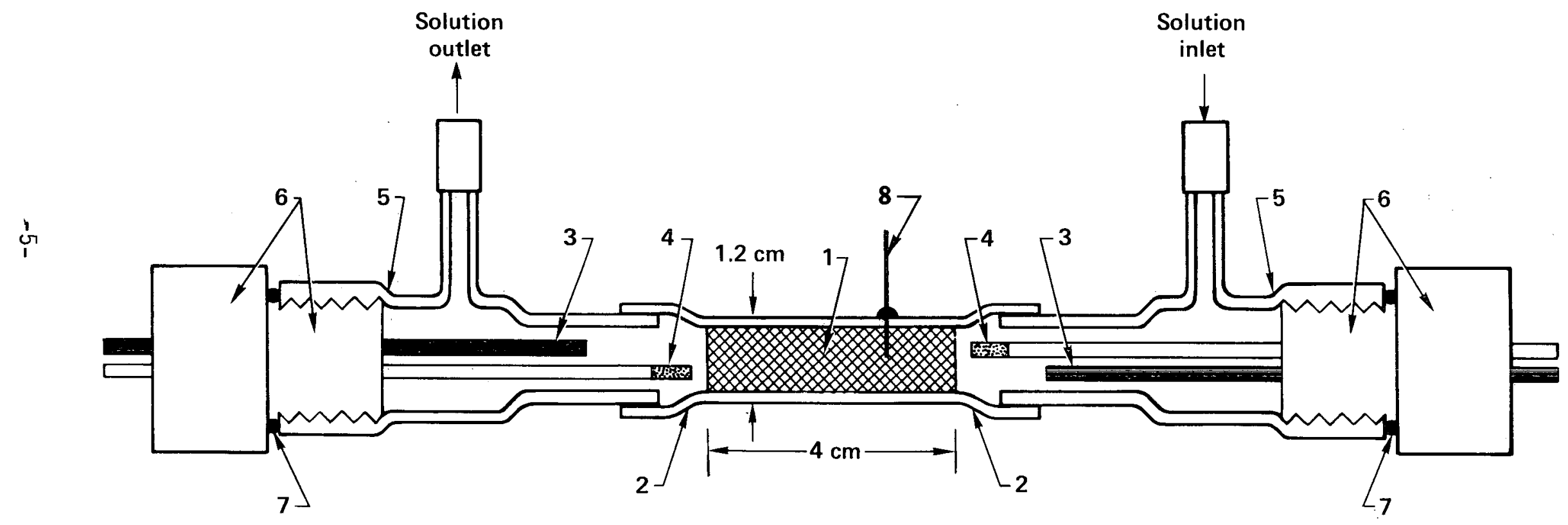

Figure 1. Flow electrolysis cell for removal of platinum from simulated geothermal brine. 1. Reticulated vitreous carbon working electrode. 2. Heat-shrinkable Tefzel tubing. 3. Glassy carbon rod counter electrodes. 4. Ag-AgCl reference electrodes. 5. Ace threaded-glass connectors. 6. Teflon plugs. 7. Viton 0-Rings. 8. Zirconium electrical connection to working electrode. 
would minimize chemical modification of the RVC during fabrication of the assembly. The dual electrodes reduce the potential gradient through the RVC and effect better control of its potential. In operation, each counter electrode and each reference electrode is connected externally to its twin.

The working-electrode cylinder of RVC was cut by means of a cork borer from pieces of RVC obtained from Energy Research and Generation, Inc. Two grades of RVC were tested: $45 S$ ( $\sim 45$ pores/in. and $800 \mathrm{ft}^{2} / \mathrm{ft}^{3}$ surface area) and 100S ( 2100 pores/in. and $2000 \mathrm{ft}^{2} / \mathrm{ft}^{3}$ surface area). For the 455 -grade material, our working electrode volume of $24.5 \mathrm{~cm}^{3}$ would have an effective surface area of $118 \mathrm{~cm}^{2}$. By comparison, the surface area of the voltammetric working electrode was $0.096 \mathrm{~cm}^{2}$.

The counter electrodes were rods of glassy carbon obtained from Polycarbon, Inc. The reference electrodes were rods of silver, coated at the top with an insulating film of Narliner strippable film, and converted to $\mathrm{AgCl}$ at the tip by immersion in aqua regia. The glass cell bodies were fabricated from Ace Glass Co. size 15 threaded connectors, and the RVC electrode was held in place by Tefzel tubing, which, as mentioned, could be shrunk at the relatively low temperature of $140^{\circ} \mathrm{C}$.

A new RVC electrode was used for each experiment; after reassembly by heat shrinking the Tefzel onto the RVC, and inserting the Teflon plugs, a needle was used to pierce the Tefzel and then a $0.5-\mathrm{mm}-\mathrm{dia}$ zirconium wire was inserted as shown in Fig. 1 to make electrical connection to the RVC. The wire was then sealed at the outside with Dow-Corning 3145 RTV sealant. A Technicon AutoAnalyzer peristaltic pump and appropriate sizes of Tygon tubing were used to pump brine through the electrolysis cell. Connection to the ports of the cell were made via Cheminert fittings. The brine was flowed through an in-line, 1-um Gelman filter before 
entering the cell. The reservoir for the platinum-containing brine that was pumped through the cell consisted of a 2-1iter FEP Teflon bottle. The cap of the bottle was fitted with a fritted-glass gas-dispersion tube for deoxygenation of the solution, and a section of Teflon tubing reaching to the bottom of the bottle for withdrawal of the solution. This tubing was connected to the pump tubing via a 3-way Teflon-plug stopcock so that the cell could first be flushed with brine that did not contain platinum.

At the beginning of each experiment, exactly 1-liter of brine was placed in the 2-liter reservoir, $1.000 \mathrm{ml}$ of the stock $\mathrm{Pt}(\mathrm{II})$ solution containing $168 \mu \mathrm{g} P \mathrm{Pt}$ was pipetted into the brine and mixed. The $\mathrm{pH}$ of this test solution was 5.1. The solution was deoxygenated with highpurity nitrogen, and then, while the flow of nitrogen continued, brine without platinum was pumped through the cell, most of the air bubbles were removed by tapping the cell, and the working electrode was preconditioned for a few minutes by polarization at the test reduction potential. Then, without interrupting the electrolys is current, and after at least 15-min. deoxygenation, the stopcock was turned to begin the flow of Pt-containing brine to the cell.

The potentiostat was an EG\&G Princeton Applied Research Model 173 with Model 176 Current Follower. Currents were integrated using an ECO (Ame1) Model 731 vigital Integrator. All experiments were carried out at an ambient temperature of $22-25^{\circ} \mathrm{C}$.

After the electrolysis, the Tefzel tubing surrounding the RVC electrode was cut, and the RVC was flushed thoroughly and quickly with water. The RVC sample was then placed in a $\mathrm{HNO}_{3}$-cleaned polyethylene vial and dried in a desiccator. The samples were analyzed for platinum by neutron activation analysis by General Activation Analysis, Inc. (San 
Diego) using the following procedure. The samples plus comparator standards were irradiated for $30 \mathrm{~min}$. in a TRIGA Mark I nuclear reactor at a flux of $1.8 \times 10^{12} \mathrm{n} / \mathrm{cm}^{2}-\mathrm{sec}$. The element platinum produces gold-199 with a half-life of 3.15 days. After a decay of nine days, the samples were counted on a $\mathrm{Ge}(\mathrm{Li})$ detector coupled to a multichannel gamma-ray spectrometer. The limit of detection of platinum in the RVC samples was $0.5 \mu \mathrm{g}$.

\section{Results and Discussion of Voltammetric Experiments}

The predominant species of platinum that would be present in the concentrated-halide geothermal brines are $\mathrm{PtCl}_{6}{ }^{2-}$ or $\mathrm{PtCl}_{4}{ }^{2-}$, depending on whether platinum is present as the +4 or +2 oxidation state. Reduction of the these species at a cathode would involve the reactions:

$$
\begin{aligned}
& \operatorname{PtCl}_{6}^{2-}+2 e^{-} \longrightarrow \mathrm{PtCl}_{4}^{2-}+2 \mathrm{Cl}^{-} \\
& \operatorname{PtCl}_{4}^{2-}+2 \mathrm{e}^{-} \longrightarrow \mathrm{Pt} \text { metal }+4 \mathrm{Cl}^{-} \\
& \operatorname{PtCl}_{6}^{2-}+4 \mathrm{e}^{-} \longrightarrow \mathrm{Pt} \text { metal }+6 \mathrm{Cl}^{-}
\end{aligned}
$$

Reactions (1) and (2) would represent the electrodeposition process if it occurred as a stepwise reduction of the $\mathrm{Pt}(\mathrm{IV})$ through $\mathrm{Pt}(\mathrm{II})$ to $\mathrm{Pt}(0)$; or Reaction (3) would represent the process if $\mathrm{Pt}$ (IV) were reduced directly to the metal. Reaction (2) corresponds to the reduction of Pt(II) to the metal.

There is some disagreement in the literature as to the exact values of the standard potentials of Reactions 1 to 3 (Milazzo and Caroli, 1978; Llopis and Colom, 1976; Lingane, 1958). However, all of the values for chloride media lie between +0.5 and $+0.75 \mathrm{~V}$ vs. the standard hydrogen electrode (SHE), and it might be expected that the electrodeposition of 
platinum could be effected at quite positive, or at least relatively low negative potentials. Unfortunately, however, both polarographic and voltammetric studies (Llopis and Colom, 1976, et seq.) have revealed that a rather large overpotential is associated with these reactions at practical current densities. Although there are no reported investigations of the voltammetry of platinum using carbon electrodes, or in strong halide media, several studies of the reduction of platinum chlorocomplexes at platinum metal electrodes (Llopis and Colom, 1976) have shown that reactions (1), (2), and (3) take place in the vicinity of -0.2 to -0.4 V vs. SHE. Accordingly, we anticipated in our studies with vitreous carbon that we would also be dealing with this electrode potential region. A practical difficulty with this characteristic is that hydrogen ion is also reduced (to $\mathrm{H}_{2}$ gas) in this potential region, and this process would tend to obscure and interfere with the platinum electrodeposition to a greater extent as the solution $\mathrm{pH}$ is lowered. Our hope, therefore, was to demonstrate that platinum could be quantitatively deposited from solutions under typical hypersaline geothermal brine conditions, without consumption of a large fraction of the current by hydrogen ion reduction.

Our examination of the voltammetry of platinum was limited in the present work to one specific set of brine conditions: $3 \underline{M}$ ( 215 wt \%) $\mathrm{NaCl}$, a $\mathrm{pH}$ range of 4 to 6 , and ambient $\left(22-25^{\circ} \mathrm{C}\right)$ temperatures. Higher temperatures such as those typical of real geothermal fluids would not be expected to change the relevant electrode potentials or reaction characteristics significantly, thus it was felt that ambient temperature tests would be sufficient to determine whether the electrolytic approach was promising. Atmospheric-flashed hypersaline brine has a pH of 5 to 6 , thus the acidity conditions of these experiments are typical of those 
found in the field. Because of the stability of the platinum chlorocomplexes, any chloride concentration in the range of 0.2 to $4 \underline{M}$ probably would yield about the same characteristics for the platinum species electrochemistry. What is not definitely known is the oxidation state of the platinum in the real geothermal brine, but because the brine is anoxic, contains $\mathrm{H}_{2} \mathrm{~S}$, and is generally mildly reducing even after loss of the $\mathrm{H}_{2} \mathrm{~S}$ through flashing, the platinum is probably present as $P t(I I)$. However, the characteristics of both Pt(IV) and Pt(II) were briefly investigated to learn the effect of the platinum speciation on the electrodeposition process.

Figure 2 shows the results of a series of voltammetric scans of a solution of $\mathrm{Pt}(\mathrm{II})$ as $\mathrm{PtCl}_{4}{ }^{2-}$ in $3 \mathrm{M} \mathrm{NaCl}$. Note that this solution of platinum corresponds to $400 \mathrm{ppm}$ Pt vs. the $50 \mathrm{ppb}$ Pt or less that might be present in a real geothermal brine. It is necessary to use these higher concentrations of platinum to study its electrochemical characteristics because the typical background currents in voltammetry would completely obscure the platinum reduction at concentrations below 1 ppm. Figure 2 shows a series of successive scans of potential, starting with a clean, bare, glassy-carbon electrode. As each scan was completed, the potentiostat was disconnected and the solution stirred briefly. Then the succeeding scan was initiated with a quiet solution. Very little reduction of the Pt(II) is evident at first, but as platinum metal accumulates on the electrode (in effect making it a platinum electrode), it becomes easier to reduce the $\mathrm{Pt}(\mathrm{II})$ species, and the height of the current peak seen in Fig. 2 increases. Apparently the rate of reduction of $\mathrm{Pt}$ (II) on a pure glassy carbon surface is very low, thus it would be necessary in an efficient recovery process to first predeposit platinum on the electrode to ensure rapid subsequent deposition of the platinum to be recovered. 


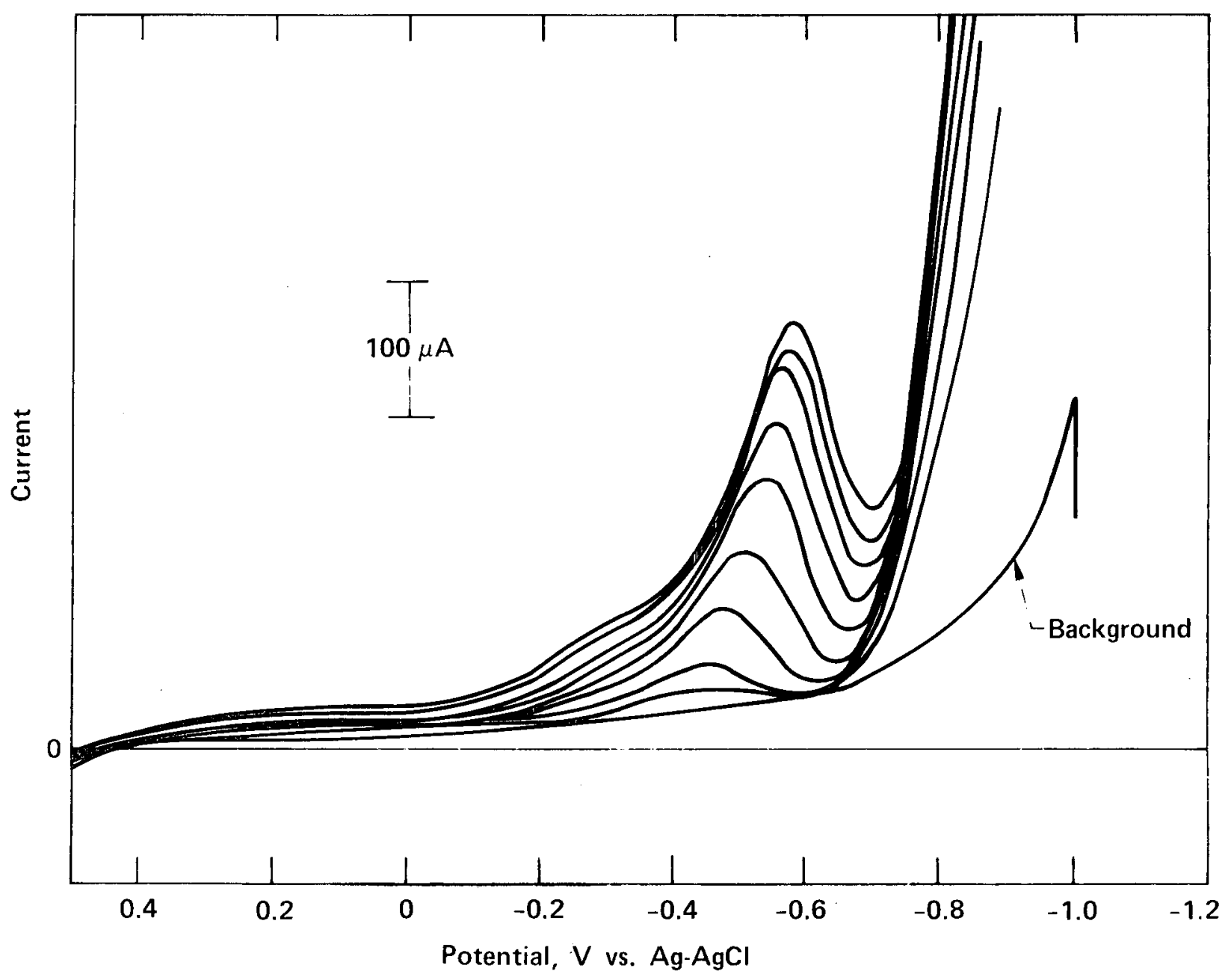

Figure 2. Redǘction of $\mathrm{Pt}(\mathrm{II})$ to $\mathrm{Pt}(0)$ on a glassy carbon electrode in $3 \underline{M}$ ( 215 wt.\%) $\mathrm{NaCl}$.

$$
\operatorname{Pt}(\mathrm{II})=2 \times 10^{-3} \underline{\mathrm{M}} \quad \text { Scan Rate }=100 \mathrm{mV} / \mathrm{sec}
$$


The potential region where $\mathrm{Pt}(\mathrm{II})$ is reduced is in general agreement with previous work using platinum electrodes as noted above. (The $\mathrm{Ag}-\mathrm{AgCl}$ reference electrode is $+0.2 \mathrm{~V}$ vs. the SHE). The nearly vertical rise in current at $-0.85 \vee(F i g .2)$ is due to the reduction of hydrogen ion to hydrogen gas, thus it is rather close to the potential required to reduce the $\operatorname{Pt}($ II $)$.

The platinum metal that has been deposited on the glassy carbon electrode can be removed by electrolytic stripping as shown by the curves of Fig. 3. In these experiments, the platinum was deposited for a given length of time by holding the electrode at $-0.7 \mathrm{~V}$ with agitation of the solution by the bubbling of nitrogen. The solution in the cell was then replaced by $3 \underline{M}$ brine not containing $P t(I I)$, and deoxygenation was carried out for $4 \mathrm{~min}$. while the potential of $-0.7 \mathrm{~V}$ was maintained on the electrode. Then the quiet, deoxygenated solutions were scanned from -0.7 to $+0.5 \mathrm{~V}$ with the results shown in Fig. 3. The fact that the platinum can be removed in this manner might be useful in an electrolytic recovery process because the carbon electrode material would not have to be destroyed and could be reused.

Figure 4 shows the behavior of $\mathrm{Pt}(\mathrm{IV})$ as $\mathrm{PtCl}_{6}{ }^{2-}$ in the high-salinity brine. No background current curve is shown; it is the same as that in Fig. 2. The curves for platinum reduction were obtained in a series of consecutive scans starting with a bare carbon surface, and again show the increased rate of reduction of $P t(I I)$ as platinum metal builds up on the electrode. The first peak in Fig. 4, which is due to the reduction of Pt(IV) to Pt(II), is apparently not sensitive to the surface composition of the electrode. No further work was done to unravel the contribution of the two consecutive reactions to the current-potential characteristics; it is evident that the constant-potential electrodeposition conditions 


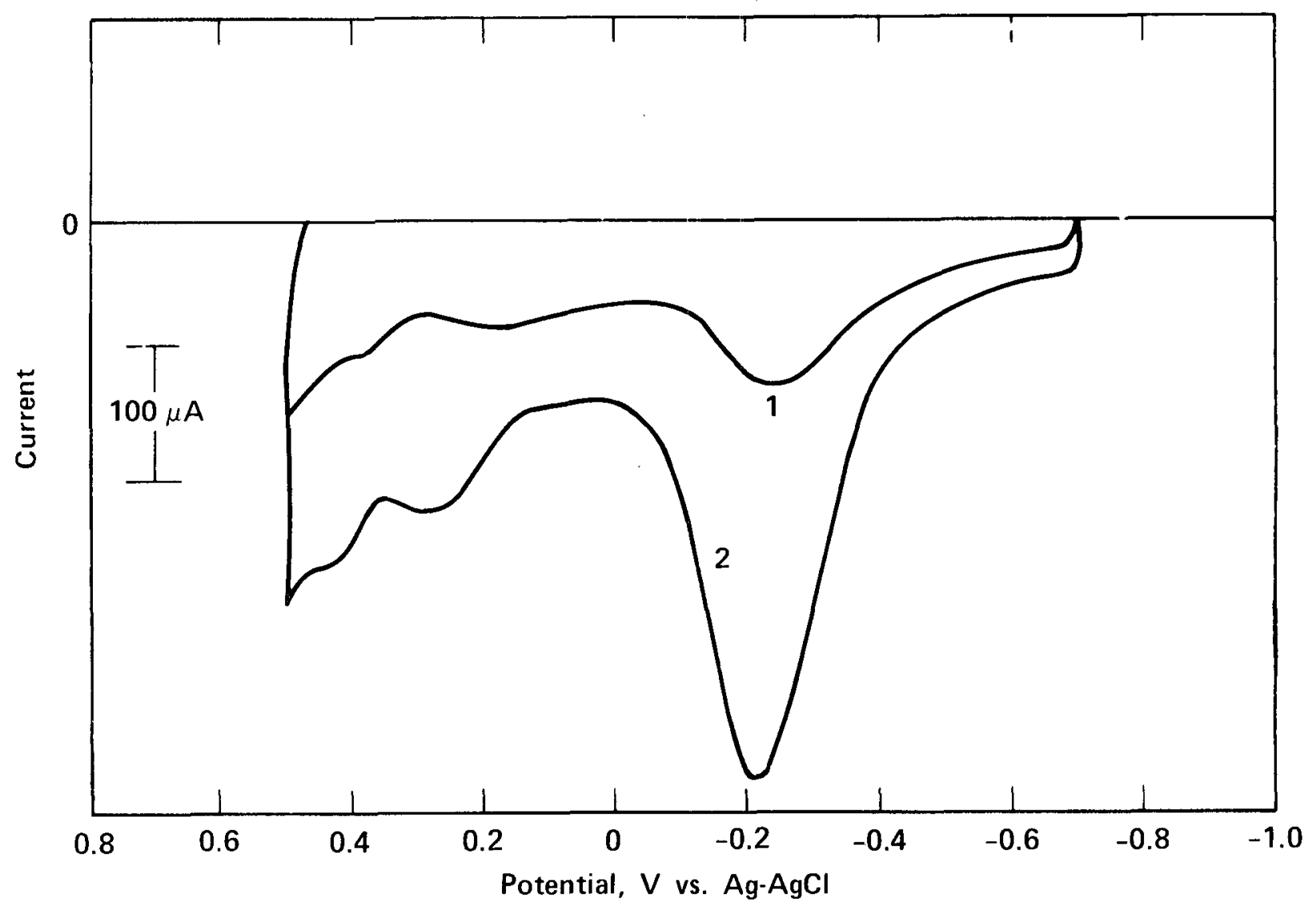

Figure 3. Anodic stripping of platinum from a glassy carbon electrode in $3 \mathrm{M}$ ( $215 \mathrm{wt} . \%) \mathrm{NaCl}$.

Scan Rate $=100 \mathrm{mV} / \mathrm{sec}$

Peak 1: After 4 min deposition from Pt(II) solution

Peak 2: After 20 min deposition from Pt(II) solution 


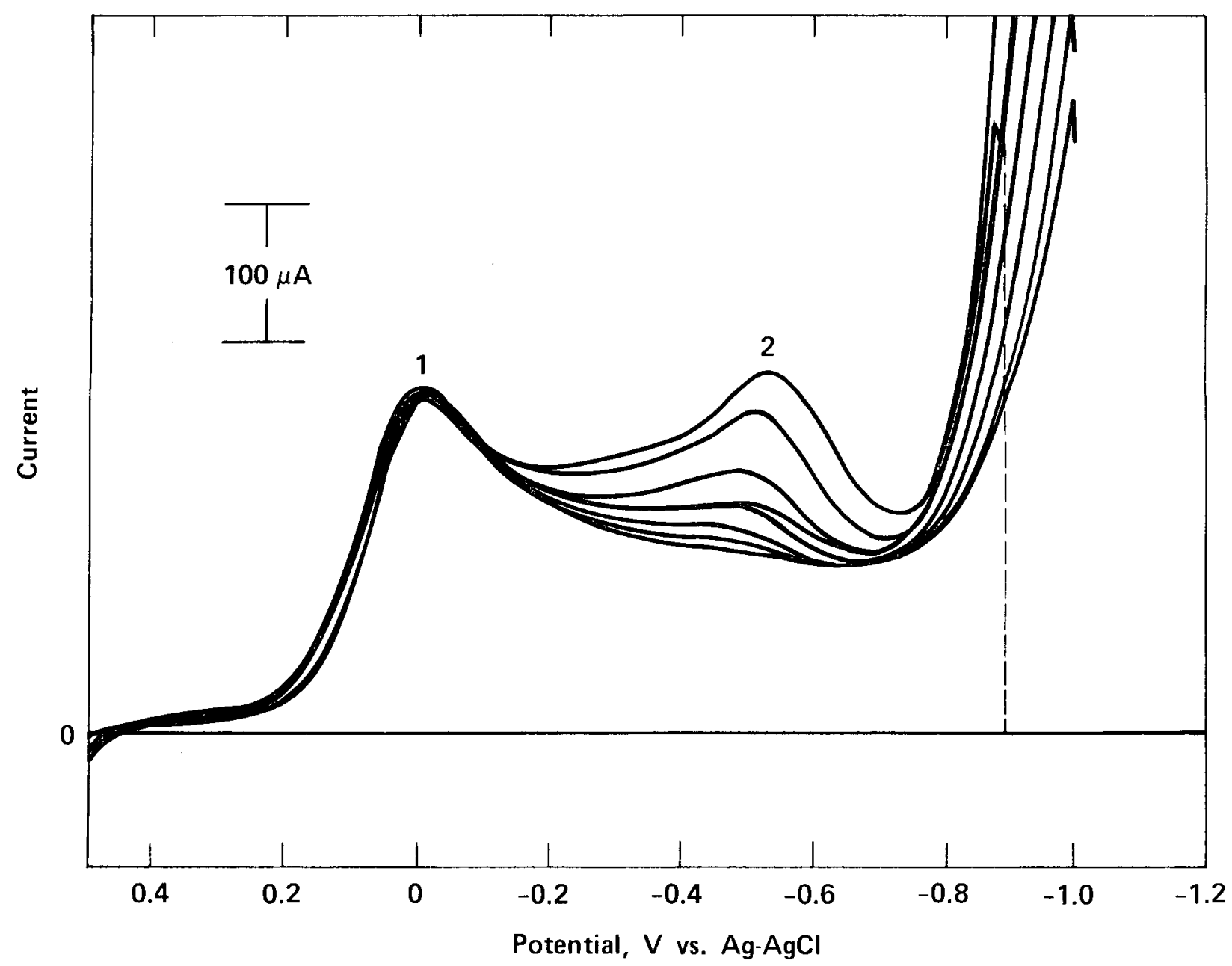

Figure 4. Reduction of $\mathrm{Pt}(\mathrm{IV})$ to $\mathrm{Pt}$ (II) and $\mathrm{Pt}(0)$ on a glassy carbon electrode in $3 \underline{M}(215 \mathrm{wt} . \%) \mathrm{NaCl}$.

$\operatorname{Pt}(\mathrm{IV})=2 \times 10^{-3} \underline{M}$

Peak 1: Pt(IV) + Pt(II)
Scan Rate $=100 \mathrm{mV} / \mathrm{sec}$

Peak 2: $\quad(P t(I I)+P t(0)$ 
must be selected to ensure that $\mathrm{Pt}(\mathrm{II})$ is reduced, whether the geothermal platinum is present as either Pt(II) or Pt(IV).

Results and Discussion of Platinum Recovery Experiments

Based on the results of the voltammetric measurements, it is obvious that the control potential would have to be at least as negative as $-0.6 \mathrm{~V}$ vs. $\mathrm{Ag}-\mathrm{AgCl}$ for complete electrodeposition of the platinum. The two complicating factors are the need to predeposit platinum to "sensitize" the carbon electrode and the proximity of the platinum reduction wave to that of hydrogen ion. A series of electrolytic recovery experiments were performed, first at $-0.60 \vee$ to examine the effect of RVC porosity and flow rate, and then at more negative potentials. The results are presented in Table 1.

These results show that the recovery of platinum was not very sensitive to the porosity (surface area) of the RVC, but was influenced significantly by the flow rate. The lowest flow rate, $1 \mathrm{ml} / \mathrm{min}$, was comparable to the flow rate found by Strohl and Curran (1979) to be necessary for quantitative electrolysis of several other species using the same porosity and similar size electrode of RVC. No preplating of platinum on the electrode was performed before the experimental runs, thus some of the lower recoveries found for the faster flow rates was due to this. At the lowest flow rate, $217 \mathrm{~h}$ was required for a run; this was believed to include enough time for sensitization of the electrode without loss of a significant fraction of the platinum.

The data in Table 1 also show that, even at the most negative potential, $-0.80 \mathrm{~V}$, the $\%$ recovery of the platinum was still relatively poor. It is known that, because of the positioning of the counter and reference electrodes, the actual potential on the interior of the RVC 
Table 1. Recovery of Platinum from $\mathrm{NaCl}$ Brine by Electrolytic Reduction.

Pt Taken: $168 \mu \mathrm{g}$ as $\mathrm{PtCl}_{4}{ }^{2-} \mathrm{NaCl}: 3 \underline{\mathrm{M}}$ ( $\left.15 \mathrm{wt} \%\right)$

Pt Concentration: $168 \mu \mathrm{g} / 1$ iter $\mathrm{pH}: 5.1$

\begin{tabular}{|c|c|c|c|c|}
\hline $\begin{array}{l}\text { Working Electrode } \\
\text { Potential, V vs } \\
\mathrm{Ag}-\mathrm{AgCl} \\
\end{array}$ & $\begin{array}{c}\text { RVC } \\
\text { Porosity } \\
\text { Grade } \\
\end{array}$ & $\begin{array}{l}\text { Flow } \\
\text { Rate } \\
\mathrm{ml} / \mathrm{min} \\
\end{array}$ & $\begin{array}{l}\text { Pt Recovered } \\
\mu \mathrm{g} \\
\end{array}$ & $\begin{array}{c}\% \\
\text { Recovery } \\
\end{array}$ \\
\hline $\begin{array}{l}\text { none (blank) } \\
-0.60\end{array}$ & $\begin{array}{l}45 S \\
45 S\end{array}$ & $\begin{array}{l}11.5 \\
11.5\end{array}$ & $\begin{array}{c}<0.5 \\
2.0,1.8,1.9\end{array}$ & 1.1 \\
\hline $\begin{array}{l}\text { none (blank) } \\
-0.60\end{array}$ & $\begin{array}{l}1005 \\
1005\end{array}$ & $\begin{array}{l}11.5 \\
11.5\end{array}$ & $\begin{array}{c}<0.5 \\
1.6,1.3\end{array}$ & 0.8 \\
\hline $\begin{array}{l}\text { none (blank) } \\
-0.60\end{array}$ & $\begin{array}{l}45 S \\
45 S\end{array}$ & $\begin{array}{l}3.9 \\
3.9\end{array}$ & $\begin{array}{c}<0.5 \\
5.2,4.9\end{array}$ & 3.1 \\
\hline $\begin{array}{l}\text { none (blank) } \\
-0.60\end{array}$ & $\begin{array}{l}100 S \\
100 S\end{array}$ & $\begin{array}{l}3.9 \\
3.9\end{array}$ & $\begin{array}{l}<0.5 \\
7.4 .7 .8\end{array}$ & 4.5 \\
\hline $\begin{array}{l}\text { non (blank) } \\
-0.60\end{array}$ & $\begin{array}{l}45 S \\
45 S\end{array}$ & $\begin{array}{l}1.0 \\
1.0\end{array}$ & $\begin{array}{r}<0.5 \\
19,11\end{array}$ & 9 \\
\hline $\begin{array}{l}\text { none (blank) } \\
-0.60\end{array}$ & $\begin{array}{l}1005 \\
1005\end{array}$ & $\begin{array}{l}1.0 \\
1.0\end{array}$ & $\begin{array}{l}<0.5 \\
12,12\end{array}$ & 7 \\
\hline $\begin{array}{l}-0.75 \\
-0.80\end{array}$ & $\begin{array}{l}1005 \\
1005\end{array}$ & $\begin{array}{l}1.0 \\
1.0\end{array}$ & $\begin{array}{c}22 \\
29,33\end{array}$ & $\begin{array}{l}13 \\
18\end{array}$ \\
\hline
\end{tabular}


matrix is less negative than the control potential at the exterior edges (Fleischmann and 0ldfield, 1971). In general, this can be compensated by employing a significantly more negative control potential. However, in this instance we must try to establish as negative a potential as possible for complete platinum reduction on the interior surfaces of the RVC, while minimizing hydrogen ion reduction and gas evolution on the edges. At the $\mathrm{pH}$ of this brine, 5 to 6 , and conceivable, practical electrolysis cell designs, this would be very difficult to achieve.

A control potential still more negative than $-0.80 \mathrm{~V}$ could be used, but then additional electrolysis current would be wasted. In our experiments, initial currents were $4-8 \mathrm{~mA}$ at $-0.60 \mathrm{~V}$ and $15-30 \mathrm{~mA}$ at $-0.80 \mathrm{~V}$. In every experiment, the current decayed to $\sim 0.5 \mathrm{~mA}$ at the end of the electrolysis. The reason for this decay or apparent "desensitization" is not known; however, it should be noted that many of the impurities in the $\mathrm{NaCl}$ that was used to prepare the brine also would be codeposited with platinum under these conditions. Based on the measured total charge that was passed, at the flow rate of $1.0 \mathrm{ml} / \mathrm{min}$, the average current was $20.7 \mathrm{~mA}$ at $-0.60 \mathrm{~V}$ and $22 \mathrm{~mA}$ at $-0.80 \mathrm{~V}$. By comparison, only $\sim 2 \mu \mathrm{A}$ would be consumed in quantitatively depositing $168 \mu \mathrm{g}$ of platinum, thus the current efficiency of the process here was very low. Real geothermal brines containing additional trace metals would require still more current; however, if the recovery were carried out using controlled-potential techniques, only $\mathrm{Pb}(\mathrm{II})$, which is found at 250-100 mg/1 concentrations in hypersaline geothermal brines, would be important. Copper, gold, silver, and cadmium, if present, also would codeposit; but manganese and zinc, which are present in high concentrations in some brines, would reqdire potentials more negative than -1.0 V vs. Ag-AgCl (Kolthoff and Lingane, 1952). 
Conclusions

Our objective in these experiments was to determine whether platinum, as the chlorocomplex in high-salinity brine, could be deposited electrolytically as the metal on a relatively inexpensive substrate with reasonable current efficiency. Reticulated vitreous carbon was found to be a convenient material to use as a working electrode, and electrodeposition of the platinum was clearly observed at millimolar concentrations (a few hundred $\mathrm{ppm}$ ). However, the process was found to require a significant overpotential, especially at the uncoated carbon surface. For the slightly acidic solutions typical of the hypersaline geothermal brine, the required control potential is close to that of the reduction of hydrogen ion. The current and energy efficiency of the process were thus unacceptably low for the very low concentration level (<1 ppm) found in the geothermal brine.

If the $\mathrm{pH}$ of geothermal brine that could be used as the input to the recovery process were higher, e.g., neutral or slightly alkaline, or if the concentrations of platinum in the brines were higher, then the electrodeposition technique would become much more favorable. A more negative control potential could then be used to obtain quantitative deposition of the platinum, and the interference by hydrogen-ion reduction would be lessened. Deliberately raising the $\mathrm{pH}$ of a geothermal brine in a processing plant by the addition of alkali, merely to facilitate platinum recovery, would not, however, prove to be economical, because of the amount of alkali that would be required. If the electrolytic removal of platinum had been successful, it is probable that the platinum could also be stripped from the carbon electrolytically by changing the control potential, thus avoiding destruction of the deposition substrate. 
It appears that the activated charcoal extraction technique investigated by Raber. Thompson, and Gregg (1984) should be the method of choice for precious metal recovery.

\section{Acknowledgement}

H. C. Crampton assisted in the fabrication of the flow-through electrolysis cell. 


\section{References}

Acton, C.F., 1982. "The Technology of Gold and Silver Extraction," in Processing of Energy and Metallic Materials, H.Y. Sohn, S.D. Hill, J.M. Wie, and K.V.S. Sastry, Eds., American Institute of Chemical Engineers, Symp. Series No. 216, Vol. 78, American Institute of Chemical Engineers, New York.

Bennion, D.N., and Newman, J., 1972. Electrochemical Removal of Copper Ions from Very Dilute Solutions, J. App1. Electrochem., 2, 113.

Coeuret, F., 1980. The Fluidized Bed Electrode for the Continuous Recovery of Metals, J. Appl. Electrochem., 10, 687.

Ettel, V.A., and Tilak, B.V., 1981. "Electrolytic Refining and Winning of Metals," in Comprehensive Treatise of Electrochemistry, Vol. 2, Electrochemical Processing, J.0'M. Bockris, B.E. Conway, E. Yeager, and R. E. White, Eds., Plenum Press, New York.

Fleischmann, M., and 0ldfield, J.W., 1971. Fluidized-Bed Electrodes, J. Electroanal. Chem., 29, 211 .

Habashi, F., 1982. Hydrometallurgy, Chem. Eng. News, February 8, pp. $46-58$.

Harrar, J.E., and Raber, E., 1983. Chemical Analyses of Geothermal Waters and Strategic Petroleum Reserve Brines for Strategic and Precious Metals, Lawrence Livermore National Laboratory Preprint UCRL-88575, Rev. 1; June. 
Kolthoff, I.M., and Lingane, J.J., 1952. Polarography, 2nd Ed., Interscience, New York, Vol. 2, pp. 468, 504.

Kuhn, A.T., 1972. "The Electrochemical Treatment of Aqueous Effluent Streams," in Electrochemistry of Cleaner Environments, J.0'M. Bockris, Ed., Plenum Press, New York, Chapt. 4.

Lingane, J.J., 1958. Electroanalytical Chemistry, 2nd Ed., Interscience, New York, p. 647.

Llopis, J.F., and Colom, F., 1976. "Platinum", in Encyclopedia of Electrochemistry of the Elements, A.J. Bard, Ed., Marcel Dekker, New York, Vol VI, Chapter VI-4.

Maimoni, A., 1983. Minerals Recovery from Salton Sea Geothermal Brines:

A Literature Review and Proposed Cementation Process, Geothermics, 11, 239.

Milazzo, G., and Caroli, S., 1978. Tables of Standard Electrode Potentials, J. Wiley, New York.

Murthy, R.S.S., Holzbecher, J., and Ryan, D.E., 1982. Trace Element Preconcentration from Aqueous Solutions on a Solid Phase, Rev. Anal. Chem. (Israel), $\underline{6}, 113$.

Raber, E., Thompson, R.T., and Gregg, D.W. 1984. An Evaluation of Sorbents for Removal of Platinum from Geothermal Brine, Lawrence Livermore National Laboratory Preprint. 
Stroh1, A.N., and Curran, D.J., 1979. Reticulated Vitreous Carbon

Flow-Through Electrodes, Anal. Chem., 51, 353.

Wang, J., 1981. Reticulated Vitreous Carbon -- A new Versitile Electrode Material, Electrochim. Acta, 26, 1721.

Wang, J., and Dewald, H.D., 1983. Deposition of Metals at a Flow-Through Reticulated Vitreous Carbon Electrode Coupled with On-Line Monitoring of the Effluent, J. Electrochem. Soc., 130. 1814. 


\section{DISCLAIMER}

This document was prepared as an account of work sponsored by an agency of the United States Government. Neither the United States Government nor the University of California nor any of their employees, makes any warranty, express or implied, or assumes any legal liability or responsibility for the accuracy, completeness, or usefulness of any information, apparatus, product, or process disclosed, or represents that its use would not infringe privately owned rights. Reference herein to any specific commercial products, process, or service.by trade name, trademark, manufacturer, or otherwise, does not necessarily constitute or imply its endorsement, recommendation, or favoring by the United States Government or the University of California. The views and opinions of authors expressed herein do not necessarily state or reflect those of the United States Government thereof; and shall not be used for advertising or product endorsement purposes.

$$
\begin{aligned}
& \text { DO NOT WOROFLM }
\end{aligned}
$$

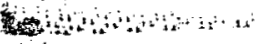

$$
\begin{aligned}
& \text { COVER }
\end{aligned}
$$

\begin{tabular}{|c|c|c|c|c|}
\hline Page Range & $\begin{array}{c}\text { Domestic } \\
\text { Price }\end{array}$ & Page Range & & $\begin{array}{l}\text { mestic } \\
\text { Price }\end{array}$ \\
\hline$\therefore 001-025$ & $\$ 7.00$ & $326-350$ & $\$$ & 26.50 \\
\hline $026-050$ & 8.50 & 351-375 & & 28.00 \\
\hline 051-075 & 10.00 & $376-400$ & & 29.50 \\
\hline $076-100$ & 11.50 & $401-426$ & & 31.00 \\
\hline $101-125$ & 13.00 & $427-450$ & & 32.50 \\
\hline $126-150$ & 14.50 & $451-475$ & & 34.00 \\
\hline 151-175 & 16.00 & $476-500$ & & $35: 50$ \\
\hline $176-200$ & 17.50 & $501-525$ & & 37.00 \\
\hline 201-225 & 19.00 & $526-550$ & $\therefore$ & 38.50 \\
\hline $226-250$ & 20.50 & $551-575$ & & 40.00 \\
\hline 251-275 & 22.00 & $576 \div 600$ & & 41.50 \\
\hline $276-300$ & 23.50 & 601-up 1 & & \\
\hline $301-325$ & 25.00 & & & \\
\hline
\end{tabular}

${ }^{1}$ Add 1.50 for eàch additional 25 page increment, or portion thereof from 601 pages up. 